\title{
Benchmarking criteria for evaluating third-party logistics providers in South Africa
}

\begin{tabular}{|c|c|}
\hline \multicolumn{2}{|c|}{$\begin{array}{l}\text { Authors: } \\
\text { Claudia Karrapan }^{1} \\
\text { Mndeni Sishange }^{2} \\
\text { Elana Swanepoel }^{1} \\
\text { Peter J. Kilbourn }^{1}\end{array}$} \\
\hline \multicolumn{2}{|c|}{$\begin{array}{l}\text { Affiliations: } \\
{ }^{1} \text { Department of Transport } \\
\text { and Supply Chain } \\
\text { Management, University of } \\
\text { Johannesburg, South Africa }\end{array}$} \\
\hline \multicolumn{2}{|c|}{$\begin{array}{l}{ }^{2} \text { Department of Business } \\
\text { Management, University of } \\
\text { Johannesburg, South Africa }\end{array}$} \\
\hline \multicolumn{2}{|c|}{$\begin{array}{l}\text { Corresponding author: } \\
\text { Peter Kilbourn, } \\
\text { pkilbourn@uj.ac.za }\end{array}$} \\
\hline \multicolumn{2}{|c|}{$\begin{array}{l}\text { Dates: } \\
\text { Received: } 31 \text { Mar. } 2017 \\
\text { Accepted: } 13 \text { June } 2017 \\
\text { Published: } 26 \text { July } 2017\end{array}$} \\
\hline \multicolumn{2}{|c|}{$\begin{array}{l}\text { How to cite this article: } \\
\text { Karrapan, C., Sishange, M., } \\
\text { Swanepoel, E. \& Kilbourn, } \\
\text { P.J., 2017, 'Benchmarking } \\
\text { criteria for evaluating } \\
\text { third-party logistics providers } \\
\text { in South Africa', Journal of } \\
\text { Transport and Supply Chain } \\
\text { Management 11(0), a305. } \\
\text { https://doi.org/10.4102/ } \\
\text { jtscm.v11i0.305 }\end{array}$} \\
\hline \multicolumn{2}{|c|}{$\begin{array}{l}\text { Copyright: } \\
\text { (C) 2017. The Authors. } \\
\text { Licensee: AOSIS. This } \\
\text { is licensed under the } \\
\text { Creative Commons } \\
\text { Attribution License. }\end{array}$} \\
\hline \multicolumn{2}{|l|}{ Read online: } \\
\hline 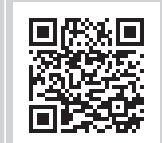 & $\begin{array}{l}\text { Scan this QR } \\
\text { code with your } \\
\text { smart phone or } \\
\text { mobile device } \\
\text { to read online. }\end{array}$ \\
\hline
\end{tabular}

Background: In South Africa, deemed the 'gateway to Africa', there is limited evidence of the existence of a survey ranking third-party logistics providers (3PLs). This lack of comparative information of the major 3PLs based on key outsourcing and ranking criteria complicates the selection process for companies that intend to contract 3PLs.

Objective: The purpose of this article was to determine the critical selection and ranking criteria for the creation of an index to evaluate 3PLs in South Africa for developing a 3PL benchmarking index.

Method: Survey data were collected from 103 of the Top 500 Companies in Africa that use 3PLs and operate within the sectors that mostly outsource logistics services in South Africa. A factor analysis method was employed.

Results: Three factors for 3PLs selection converged: service quality, information management and compliance, and collaboration. The top three ranked categories for 3PLs selection are cost and price structure, service delivery and the relationship with the 3PL provider. Most respondents $(90 \%)$ confirmed a need for a 3PLs index in South Africa.

Conclusion: The results help managers with the strategic selection of 3PLs as these critical logistics outsourcing selection criteria can be used to evaluate and rank 3PLs prior to contracting. Based on the selection criteria for logistics outsourcing identified and ranked in this article, a ranking index for 3PLs in South Africa can be developed.

\section{Introduction and background}

The outsourcing of logistics services has become popular with companies globally because of the potential it holds for the creation of more effective and efficient logistics systems. Globally, the third-party logistics provider (3PL) industry has grown rapidly (Armstrong \& Associates 2014) offering a range of services, including the commonly outsourced activities of warehousing, logistics and freight forwarding, as well as value-add services such as order management and fulfilment, information technology (IT) services and supply chain consultancy (Langley \& Capgemini 2014).

The process of outsourcing logistics services involves finding, evaluating and selecting suitable 3PLs. Firms that decide to outsource can choose from an array of 3PLs operating globally and in South Africa. Qureshi, Kumar and Kumar (2007) advised that owing to the potential impact of logistics outsourcing on the competitiveness of a client organisation, the selection process used to find a 3PL demands detailed research to ensure that expectations of the user are met. This process can be facilitated through the use of a ranking index of 3PLs serving a specific market.

There exist a number of major international ranking indexes of 3PLs, including those provided by Gartner (2013) and Armstrong and Associates (2015). These indexes are based on a broad range of criteria. The ranking index report provided by Armstrong and Associates (2014) includes information on various attributes and services of 3PLs, namely: turnover, service area, assets, information systems, services and key customers. These ranking indexes could provide valuable assistance to potential logistics outsourcing clients as well as existing 3PLs in benchmarking themselves against competitors.

Various studies have explored the issue of 3PL selection criteria, including those of Menon, McGinnis and Ackerman (1998); Braglia and Petroni (2000); Qureshi et al. (2007); Bayazit and Karpak (2013) and Aguezzoul (2014). Resulting from these studies is a wide variety of 3PL selection criteria which varies in its importance and relevance to prospective users. This result 
could be expected based on the view that a wide range of logistics services are outsourced by firms with different business strategies and capabilities.

Although a broad set of 3PLs selection criteria is available from the literature, it seems that no single criterion is sufficient for selection. It is essential for potential users of 3PLs to identify and classify key criteria relevant to them in the selection of service provider(s). To establish a ranking index for a specific country's 3PL providers, it is therefore necessary to examine 3PL selection criteria in the country's own context and use the theory presented by the various studies to develop a list of selection criteria that is relevant and important to the users of 3PLs in that country.

\section{Problem statement}

Several global researchers have published 3PL indexes to rank international logistics service providers based on a broad set of criteria. These global reports focus on North and South America, Asia and Europe with very little or no information on Africa or South Africa, in particular.

In South Africa, deemed the 'gateway to Africa', there is limited evidence of an index providing a ranking or comparison of 3PLs available to the local market. Two supply chain related reports are regularly published but neither of these include a comparison of 3PLs. Barloworld Logistics (2017) annually publishes a report entitled 'Supplychainforesight', focusing on a variety of relevant supply chain issues. Since 2016, Stellenbosch University publishes the 'Logistics Barometer' presenting the national logistics costs in a standardised, internationally benchmarked format. The latter report replaced the CSIR (2014) 'Annual State of Logistics Report', discontinued in 2014. However, none of these reports provide a list or ranking index of 3PLs available to potential local users of such companies.

The research problem therefore is that currently there is a lack of comparative information of the major 3PLs in South Africa based on key outsourcing and ranking criteria. This makes the selection process difficult for companies that intend to contract 3PLs. The purpose of this article is to establish which key outsourcing criteria are important to South African users when evaluating 3PLs and to determine how these users rank the criteria. This information can contribute to the establishment of a future ranking index for 3PLs in South Africa and can be extended to other developing and developed countries.

The remainder of this article is organised as follows: Firstly, a literature review is provided which makes provision for a discussion of key concepts and the identification of 3PL selection criteria to be evaluated in the context of this study. Then a discussion of the research methodology followed, results obtained, study conclusions and, finally, limitations of the study are presented.

\section{Literature review Third-party logistics}

3PLs are those companies that specialise in providing services such as transportation (inbound and outbound), warehousing, freight forwarding and customs clearance' (Jim Wu 2006:505). Wanke (2012:2424) defined a 3PL more comprehensively as 'the integrated logistics service provider that is prepared to satisfy all or most of a client's logistics needs in a customised way'.

Logistics outsourcing is defined as 'a provision of a single or multiple logistics services by a vendor on a contractual basis' (Mothilal et al. 2012:2409). Soinio, Tanskanen and Finne (2012) suggested that logistics outsourcing is a growing business, and services which are outsourced to 3PLs have shifted from being a single type of service to a broader range of services, including advanced supply chain solutions, resulting in an increase in the trend of logistics outsourcing. Most major sectors, such as information technology, automotive, fast-moving consumer goods (FMCG) and pharmaceutical and retail sectors outsource their logistics services to 3PLs (Mothilal et al. 2012). Firms can choose to manage logistics activities in-house or decide to outsource specific activities as a strategic move thereby establishing a competitive advantage to outmanoeuvre rivals in the market place (Brewer, Wallin \& Ashenbaum 2014).

The reduction of costs is a popular reason for the outsourcing of logistics services (Jacoby 2009; Wanke 2012). However, there are various other potential advantages associated with logistics outsourcing such as the offloading of capital intensive logistics assets and access to the best information systems and a range of value-added services (Jacoby 2009). In addition, through logistics outsourcing a company can improve customer service levels, increase operational flexibility and enhance the ability to focus on core competencies (Qureshi et al. 2007; Wanke 2012). Furthermore, logistics outsourcing enables a company to convert fixed costs into variable costs (Bayazit \& Karpak 2013) and achieve strategic objectives (Qureshi, Abdelhadi \& Shakoor 2014). Outsourcing to 3PLs has the potential for measurable benefits as found by Langley and Capgemini (2014), who measured the tangible benefits to shippers of such outsourcing. They measured reductions in logistics costs, inventory costs and logistics fixed asset values, while an improvement was measured in order fill rate and order accuracy. Outsourcing therefore has the potential to make logistics systems more efficient and effective. High performing logistics systems in turn, enable companies to improve customer service levels and gain a competitive advantage (Diabat et al. 2013).

By means of logistics outsourcing external resources can be leveraged to either manage the entire logistics system or only specific logistics activities. According to Liu et al. (2014), outsourcing activities can be grouped into three areas: basic, customised and advanced, depending on the requirements of the company. Logistics outsourcing therefore can include a 
broad range of services including: planning, implementing and controlling of physical flows; storage of raw materials; and management of in-process inventories and finished goods (Liu et al. 2014). It can further include direct transportation services, warehouse management, shipment consolidation, freight forwarding and payment, order processing and vendor management (Liu et al. 2014).

Chen et al. (2010) indicated that organisations mostly outsource those logistics activities that are perceived to be non-core activities. For the 18th Annual Third-Party Logistics Study (Langley \& Capgemini 2014), shippers were surveyed globally to establish the most commonly outsourced services. The survey showed that the most commonly outsourced services are grouped under operational and repetitive activities and include: domestic and international transportation $(81 \%$ and $78 \%$, respectively), warehousing $(73 \%)$, freight forwarding $(62 \%)$ and customs brokerage (57\%). Shippers indicated that a fair amount of value-added services (second category) are outsourced; including cross docking (36\%), reverse logistics $(36 \%)$, freight-bill auditing (33\%), product labelling and packaging $(32 \%)$, transportation planning and management (28\%) and supply chain consultancy services (25\%). In the third category, a moderate outsourcing of strategic and IT intensive services takes place. Examples of these activities include IT services, order management and fulfilment, inventory management, fleet management, lead logistics providers or fourth-party logistics (4PL) services, customer services, service parts logistics and sustainability or green supply chain services (Langley \& Capgemini 2014). It therefore appears that the logistics outsourcing industry is a sizeable industry which is still growing.

While different processes can be followed to source 3PLs, they require the identification of potential 3PLs and the critical evaluation of their services against a set of predetermined criteria. Coyle et al. (2009) has developed a seven-step strategic sourcing methodology which requires the evaluation of all suppliers, including sourcing of 3PLs. Qureshi et al. (2007) developed a 3PL sourcing process that will meet the criteria of the user of such service. In this process the user develops objectives and criteria for the request for proposals (RFPs) and then evaluates the RFP responses against an integrated model to identify and classify key criteria. As approximately $60 \%$ of the Fortune 500 companies in the United States have a partnership agreement with a 3PL service provider (Aguezzoul 2014), the need for selection criteria to conduct comparative analysis would exist. In South Africa, such information regarding 3PL selection criteria is still lacking.

\section{Third-party logistics service provider indexes - comparative analyses}

3PL surveys which provide a ranking of service providers can be useful to prospective outsourcing clients. Surveys that rank 3PLs include those conducted by Gartner (2013) and Armstrong and Associates (2015). Gartner (2013) developed the 'Magic quadrant for global 3PL providers' based on 3PLs' capabilities to provide value-add services in being innovative and eliminating waste in supply chains, categorising the service providers into one of four quadrants: challengers, players, niche players and visionaries. The value provided by the Gardner survey is illustrated by its 2013 report where four 3PLs were classified as 'leaders', four as 'challengers', four as 'niche players' and none as 'visionaries'. The magic quadrant serves as a tool to assist logistics managers to understand better the capabilities of 3PLs when selecting a service provider (Gartner 2013). Gartner's (2013) report also provides valuable suggestions such as that 3PLs could provide more strategic forecasting and direction to shippers.

While Gartner (2013) focused more on value-adding services, such as forecasting and innovation, Armstrong and Associates (2015) publish annual 3PL reports, such as the Top 50 global 3PLs, Top 20 North American 3PLs and Top 30 United States domestic 3PLs. These reports rank 3PLs according to their revenue generation, service area coverage, assets, IT and services and key customers, but predominantly based on revenue generation.

3PL rankings indexes therefore serve various purposes and are based on different sets of criteria. For the development of a South African based 3PL index it is a prerequisite to first examine logistics service provider selection criteria in the South African context by using the theory presented by various studies to derive a list of selection criteria that could be relevant and important to the users of 3PLs in South Africa.

\section{Ranking the third-party logistics service provider selection criteria}

Aguezzoul (2014) conducted a literature review on criteria and methods pertaining to the "Third-party logistics selection problem'. The author's review of 67 articles published between 1994 and 2013 reveals that 3PL selection is empirical in nature and is related to a region or country, industrial sector and the logistics activities outsourced.

According to Aguezzoul (2014), some 3PL selection criteria have common application while others are tailored to specific customer requirements. In addition, a firm's competitiveness strategy and external environment affect 3PL selection criteria. Nevertheless, Aguezzoul (2014) identified a list of criteria deemed important when selecting a 3PL and these are synthesised with those identified by Bayazit and Karpak (2013), Braglia and Petroni (2000), Menon et al. (1998) and Qureshi et al. (2007) (refer to Table 1). All these authors identified 23 selection criteria of which 15 were identified by multiple authors: quality of service, information technology capability, delivery performance, trustworthiness, operational performance, compatibility, financial stability, geographic spread and range of services, long-term relationship, reputation, price and optimum cost, surge capacity, flexibility in operation and delivery, on-time delivery, low error rates and creative management.

Because of the strategic nature of the outsourcing decision, it is logical to assume that prospective outsourcing clients 
TABLE 1: Third-party logistics service provider selection criteria.

\begin{tabular}{|c|c|}
\hline 3PLs selection criteria & Authors \\
\hline Quality of service & $\begin{array}{l}\text { Bayazit and Karpak (2013); Menon et al. (1998); } \\
\text { Qureshi et al. (2007) }\end{array}$ \\
\hline Size and quality of fixed assets & Qureshi et al. (2007) \\
\hline Quality of management & Qureshi et al. (2007) \\
\hline Information technology capability & $\begin{array}{l}\text { Bayazit and Karpak (2013); Braglia and Petroni } \\
\text { (2000); Qureshi et al. (2007) }\end{array}$ \\
\hline Delivery performance & $\begin{array}{l}\text { Aguezzoul (2014); Menon et al. (1998); Qureshi } \\
\text { et al. (2007) }\end{array}$ \\
\hline Trustworthiness & Bayazit and Karpak (2013); Qureshi et al. (2007) \\
\hline Operational performance & Aguezzoul (2014); Qureshi et al. (2007) \\
\hline Compatibility & Bayazit and Karpak (2013); Qureshi et al. (2007) \\
\hline Financial stability & $\begin{array}{l}\text { Aguezzoul (2014); Bayazit and Karpak (2013); } \\
\text { Braglia and Petroni (2000); Menon et al. (1998); } \\
\text { Qureshi et al. (2007) }\end{array}$ \\
\hline $\begin{array}{l}\text { Geographical spread and range of } \\
\text { services }\end{array}$ & $\begin{array}{l}\text { Bayazit and Karpak (2013); Braglia and Petroni } \\
\text { (2000); Qureshi et al. (2007) }\end{array}$ \\
\hline Long-term relationship & Bayazit and Karpak (2013); Qureshi et al. (2007) \\
\hline Reputation & $\begin{array}{l}\text { Bayazit and Karpak (2013); Braglia and Petroni } \\
\text { (2000); Qureshi et al. (2007) }\end{array}$ \\
\hline Price and optimum cost & $\begin{array}{l}\text { Aguezzoul (2013); Menon et al. (1998); Qureshi } \\
\text { et al. (2007) }\end{array}$ \\
\hline Surge capacity & Qureshi et al. (2007); Braglia and Petroni (2000) \\
\hline Flexibility in operation and delivery & Bayazit and Karpak (2013); Qureshi et al. (2007) \\
\hline On-time delivery & $\begin{array}{l}\text { Aguezzoul (2014); Bayazit and Karpak (2013); } \\
\text { Menon et al. (1998) }\end{array}$ \\
\hline $\begin{array}{l}\text { Responsiveness to unforeseen } \\
\text { circumstances }\end{array}$ & Aguezzoul (2014) \\
\hline Low error rates & Aguezzoul (2014); Menon et al. (1998) \\
\hline Creative management & $\begin{array}{l}\text { Aguezzoul (2014); Braglia and Petroni (2000); } \\
\text { Menon et al. (1998) }\end{array}$ \\
\hline Top management commitment & Menon et al. (1998) \\
\hline Availability of top management & Aguezzoul (2014) \\
\hline $\begin{array}{l}\text { Ability to meet contractual } \\
\text { requirements }\end{array}$ & Menon et al. (1998) \\
\hline Ability to solve problems & Menon et al. (1998) \\
\hline \multicolumn{2}{|c|}{$\begin{array}{l}\text { Source: Aguezzoul (2014:70-77), Bayazit and Karpak (2013:20-13), Qureshi et al. } \\
\text { (2007:227-245), Braglia and Petroni (2000:96-111) and Menon et al. (1998:121-137) }\end{array}$} \\
\hline \multicolumn{2}{|c|}{$\begin{array}{l}\text { Note: Please see the full reference list of the article, Karrapan, C., Sishange, M., Swanepoel, } \\
\text { E. \& Kilbourn, P.J., 2017, 'Benchmarking criteria for evaluating third-party logistics providers } \\
\text { in South Africa', Journal of Transport and Supply Chain Management } 11(0) \text {, a305. https:// } \\
\text { doi.org/10.4102/jtscm.v11i0.305, for more information. }\end{array}$} \\
\hline 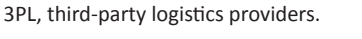 & \\
\hline
\end{tabular}

should not only identify appropriate criteria for selecting 3PLs, but that such selection criteria should be ranked in terms of its importance for users. These selection criteria will ultimately be used to select 3PLs which best match the outsourcing requirements of clients. An example of such a ranking is that of a 3PL survey that was conducted during the 13th Annual State of Logistics Outsourcing (IOMA 2009:1012) to establish and rank the most important 3PL selection criteria. Reputation, proven track record and industry expertise was identified as the most important criterion at $51 \%$, followed by cost savings and price (39\%), ability to solve problems and partner with user (37\%), flexibility (20\%), technology $(12 \%)$, infrastructure capabilities $(10 \%)$ and financial stability $(10 \%)$.

Earlier empirical studies conducted by Moberg and Speh (2004) and Spencer, Rogers and Daugherty (1994), investigating the process of selecting a 3PL service provider, identified additional criteria which were ranked differently to those of the IOMA (2009). Moberg and Speh (2004) studied selection specifically for delivering warehouse functions among 155 firms and isolated 12 selection criteria used when choosing 3PLs (ranked in Table 2). In addition, Spencer et al.
TABLE 2: Ranking of third-party logistics service provider selection criteria.

\begin{tabular}{|c|c|c|}
\hline Ranking & Spencer et al. (1994) & Moberg and Speh (2004) \\
\hline 1. & On-time performance & Responsiveness to service requests \\
\hline 2. & Service quality & Quality of management \\
\hline 3. & Good communication & Track record \\
\hline 4. & Reliability & Ability to provide value-added services \\
\hline 5. & Speed & Low costs \\
\hline 6. & Flexibility & Specific channel expertise \\
\hline 7. & Customer support & Knowledge of the market \\
\hline 8. & Easy to work with & Personal relationships with key contacts \\
\hline 9. & Management quality & Willingness to assume risk \\
\hline 10. & Early notification of disruptions & $\begin{array}{l}\text { Investment in state of the art } \\
\text { technology }\end{array}$ \\
\hline 11. & Order cycle time & Size \\
\hline 12. & Willingness to customise service & National market coverage \\
\hline 13. & Reputation & - \\
\hline 14. & Price & - \\
\hline 15. & Location & - \\
\hline 16. & Variety of available services & - \\
\hline 17. & Cost reduction & - \\
\hline 18. & Special expertise & - \\
\hline 19. & Decreased labour problems & - \\
\hline 20. & Technical competence & - \\
\hline 21. & Decreased asset commitment & - \\
\hline 22. & Increased competition & - \\
\hline 23. & Global capabilities & - \\
\hline
\end{tabular}

Source: Spencer et al. (1994:60-74) and Moberg and Speh (2004:71-76)

Note: Please see the full reference list of the article, Karrapan, C., Sishange, M., Swanepoel, E. \& Kilbourn, P.J., 2017, 'Benchmarking criteria for evaluating third-party logistics providers in South Africa', Journal of Transport and Supply Chain Management 11(0), a305. https:// doi.org/10.4102/jtscm.v11io.305, for more information.

(1994) surveyed 154 firms and identified 23 criteria, ranked based on importance (refer to Table 2). It is clear from Table 2 that the rankings provided by these two studies are different.

\section{Conclusions from literature review}

Although users are specific about their requirements when selecting 3PLs; these requirements and their importance may differ depending on the requirements of users. There is, however, a substantial overlap in the selection criteria presented by the various authors. For this study, a combination of the selection criteria from international studies was used owing to a total lack of similar information in South Africa.

From the literature study 44 selection criteria were identified for use in the survey to determine those criteria relevant and important to the South African logistics industry. This allowed for a comprehensive analysis. The 44 criteria were gleaned from a qualitative literature analysis, not a quantitative analysis. The selected criteria were collated mostly from Menon et al. (1998), Qureshi et al. (2007), Bayazit and Karpak (2013), Braglia and Petroni (2000) and Aguezzoul (2014). Prior to their use in this study, the criteria selected were submitted to a consultant who is an industry expert for evaluation and to improve face validity.

The 44 criteria were grouped into the following seven categories, each containing several criteria:

- credentials of 3PLs (6 criteria)

- potential relationship with 3PLs (5 criteria)

- scope of services offered by 3PLs (8 criteria) 
- cost and pricing structure of 3PLs (5 criteria)

- service delivery of 3PLs (5 criteria)

- 3PL resources and technical capability (9 criteria)

- quality of 3PLs (6 criteria).

These categories were used in this study to determine the importance of the various selection criteria used by 3PL clients in South Africa and to conduct the ranking study. Each one of these criteria can be defined by a set of attributes. To ensure a common understanding of the selection criteria, Aguezzoul's (2014) definitions (refer to Table 3) of the 11 key selection criteria he identified were used when developing the 3PL selection criteria for this survey.

\section{Research methodology}

This cross-sectional exploratory study adopted a positivistic epistemology (Saunders, Lewis \& Thornhill 2012), employing a quantitative method using a survey strategy and electronic structured questionnaires to identify the selection and ranking outsourcing criteria. The questionnaire was pilot tested with 10 respondents. The pilot test assisted in confirming that there was adequate construct validity in the questionnaire. The reason for using a quantitative method is that a sizeable study sample was required for the determination of key selection criteria across different industry sectors and numerical data was required for the ranking of these criteria.

\section{Target population and sampling}

Owing to the nature of the data required, the unit of analysis comprised of managers and logistics practitioners employed by companies that contract 3PLs. It was thus necessary to first identify the industry sectors that predominantly contract 3PLs. From telephonic interviews with the five top-ranked 3PLs on the Armstrong and Associates (2013b) list and operating in South Africa, as well as a further five wellknown South African 3PLs, the industries that mostly contract 3PLs were identified. Although the database, 'Top 500 Companies in Africa' (2013), includes companies from eight industry sectors, only those from the five identified industry sectors were targeted: Energy, chemicals and gas (52), manufacturing - automotive and pharmaceuticals (46), mining and construction (36), technology and communication (44) and retail and FMCG and perishables (47). The target population consisted of a total of 225 South African companies within these industry sectors. The survey questionnaire was distributed to all 225 companies. To ensure compliance with the inclusive criterion, a filter question differentiated users of 3PLs from non-users, resulting in 103 (46\%) valid responses. Cronbach's alpha value was used to assess reliability. Factor analysis was conducted to test if the scales used were unidimensional. The results for the reliability and validity testing are discussed in a later section.

\section{Results \\ Profile of respondents}

Participating companies operated in the following industry sectors: mining $(27 \%)$, wholesale and retail (24\%), manufacturing (21\%), diversified $(19 \%)$, construction $(16 \%)$, telecoms and communication $(8 \%)$, technology $(7 \%)$ and other $(7 \%)$. The positions of respondents in the companies ranged from chief executive officers or general managers $(6 \%)$, operations managers $(5 \%)$, procurement $(37 \%)$, supply chain $(31 \%)$, to logistics $(12 \%)$ and with 'other in 3PL selection' (10\%). Thus, the respondents had the knowledge necessary to respond meaningfully to the survey questions. With regard to the type of logistic services that are outsourced, 403 responses were recorded, indicating that most respondents outsourced more than one function to 3PLs. The top five logistics services that are outsourced are transportation $(99 \%)$, customs clearance $(83.5 \%)$, freight forwarding $(83.5 \%)$, freight billing $(70.9 \%)$ and warehousing (37.9\%).

TABLE 3: Descriptions of third-party logistics service provider selection criteria.

\begin{tabular}{|c|c|}
\hline Criterion & Description or definition \\
\hline Cost & $\begin{array}{l}\text { It refers to the total cost of logistics outsourcing. Its related attributes include price, cost reduction, low-cost distribution, expected leasing cost, } \\
\text { operation cost, warehousing cost and cost savings. }\end{array}$ \\
\hline Relationship & $\begin{array}{l}\text { It includes shared risks and rewards, and cooperation between the user and the 3PL. It also helps in controlling 3PL opportunistic behaviour. Reliability, } \\
\text { truth, dependence, alliance, compatibility and reciprocity are among its attributes. }\end{array}$ \\
\hline Services & $\begin{array}{l}\text { It is related to attributes such as breadth of services, characterisation or specialisation of services, variety of available services, pre-sale or post-sale } \\
\text { customer services and value-added services. }\end{array}$ \\
\hline Quality & $\begin{array}{l}\text { Quality of the 3PL includes many aspects such as, commitment to continuous improvement, SQAS and ISO standards environment issues, and risk } \\
\text { management. }\end{array}$ \\
\hline $\begin{array}{l}\text { Information equipment } \\
\text { systems }\end{array}$ & $\begin{array}{l}\text { It corresponds to physical equipment and information systems that facilitate communication and execution of logistics operations of its customers. It is } \\
\text { related to attributes such as EDI, tracking or tracing, technology capabilities, information accessibility, availability of computer network, technical or } \\
\text { engineering capability, materials handling equipment and information security. }\end{array}$ \\
\hline Flexibility & $\begin{array}{l}\text { Ability to adapt to changing customers' requirements and circumstances. Its attributes include ability to meet future requirement, capacity to } \\
\text { accommodate and grow the client's business, system flexibility index, responsiveness to target market or service requests, capability to handle specific } \\
\text { business requirements and time response capability. }\end{array}$ \\
\hline Delivery & $\begin{array}{l}\text { It is represented by attributes such as time, on-time performance, on-time shipment and deliveries, delivery speed, accuracy of transit or delivery time, } \\
\text { shipment delivery and on-time delivery rate. }\end{array}$ \\
\hline Professionalism & $\begin{array}{l}\text { The 3PL exhibits sound knowledge of services in the industry and display punctuality and courtesy in the way they interact and present to the } \\
\text { customers. It is characterised by attributes such as expertise, competence and experience. }\end{array}$ \\
\hline Financial position & $\begin{array}{l}\text { A sound financial performance of the } 3 \mathrm{PL} \text { ensures continuity of service and regular upgrading of the equipment and services, which are used in logistics } \\
\text { operations. }\end{array}$ \\
\hline Location & $\begin{array}{l}\text { It is related to attributes such as distribution coverage, geographical specialisation and coverage, international scope, market coverage, shipment } \\
\text { destinations and distance. }\end{array}$ \\
\hline Reputation & It refers to the opinion of the customers about how good the 3PL are in satisfying their needs. This is more relevant in the initial screening of 3PL. \\
\hline
\end{tabular}

Source: Aguezzoul, A., 2014, 'Third party logistics selection problem: A literature review on criteria and methods', Omega 49, 75. https://doi.org/10.1016/j.omega.2014.05.009

3PL, third-party logistics providers; SQAS, Safety and Quality Assessment System; ISO, International Organisation for Standardisation; EDI, Electronic Data Interchange. 


\section{Selection criteria for third-party logistics outsourcing}

The 44 selection criteria for 3PL outsourcing were grouped into seven categories. The importance of each criterion was rated on a five-point Likert-type scale $(1=$ not important; 2 = moderately important; 3 = important; 4 = very important; $5=$ extremely important). All the Cronbach alpha values for the seven categories were more than 0.6: A1 - 0.613 (after the deletion of one item), A2 - 0.652, A3 - 0.759, A4 - 0.636, A5 0.873, A6 - 0.848 and A7 - 0.899. According to Pallant (2007), Cronbachs alpha values of less than 0.7 are low. However, Pallant (2013) states:

Cronbach Alpha values are, however, quite sensitive to the number of items in the scale. With short scales (e.g. scales with fewer than ten items) it is common to find quite low Cronbach values (e.g. .5). (p. 101)

Category A1 had five items after the deletion of one item. For this reason the reliability results were accepted with caution. It is suggested that the construct scales used in this study be retested and further refined in the future.

Of the five remaining criteria in the Credentials of the $3 P L$ service provider category (A1), two had mean scores greater than 4.0, namely demonstration of innovation by the 3PL service provider (4.47) and accessibility of top management (4.17). Of the five criteria in the Potential relationship with 3PL service provider category (A2), two had mean scores higher than 4.0, namely the sharing of risks between this organisation and the $3 P L$ service provider (4.38) and sharing rewards between this organisation and the 3PL service provider (4.05). Of the eight criteria in the Scope of $3 P L$ services category (A3), three had mean scores higher than 4.0, namely the ability of the 3PL service provider to provide value-added services (4.52), the ability of the 3PL service provider to provide a customised service (4.34) and geographical coverage of the 3PL service provider (4.21). Of the five criteria of the Cost and pricing structure of the 3PL service provider category (A4), three had mean scores higher than 4.0, namely cost savings offered by the 3PL service provider (4.12), low operation cost of the $3 P L$ service provider (4.08) and favourable price structure of $3 P L$ service provider (4.01). Of the five criteria of the Service delivery of the 3PL service provider category (A5) four had mean scores higher than 4.0; namely adherence to the contract (4.27), on-time shipment and deliveries (4.18), accuracy of delivery (4.16) and low error rates (4.13). Of the nine criteria of the $3 P L$ resources and technical capability category (A6) three had mean scores higher than 4.0, namely information management and reporting (4.49), information network security (4.38) and information network accessibility (4.12). Of the six criteria of the Quality of the 3PL service provider category (A7), three had mean scores higher than 4.0, namely commitment to continuous improvement from the 3PL service provider (4.55). Information management and compliance and risk management (4.12) and quality of management by the 3PL service provider (4.07).

The overall mean score value for all categories of selection criteria is 3.91 which is a close approximation of an 'agreed' response on a five-point scale. This result suggests the relevance of the criteria used in the survey. The overall mean score values per category of selection criteria allowed the following ranking: category A5 Service delivery of the 3PL service provider (4.14), category A7 Quality of the 3PL service provider (4.03), category A2 Potential relationship with 3PL service provider (4.01), category A1 Credentials of the $3 P L$ service provider (4.17), category A4 Cost and pricing structure of 3PL service provider (3.91), category A3 Scope of 3PL services (3.68) and category A6 3PL resources and technical capabilities (3.64). From these results it appears that four of the categories were rated very important as selection criteria and three categories were rated as important. Noteworthy is the fact that the highest mean score value was assigned to the category A1: Credentials of the 3PL service provider (4.17). This category included the following selection criteria: Turnover of the 3PL service provider, financial stability of the 3PL service provider, Accessibility of top management of the 3PL, Reputation of the 3PL service provider and demonstration of innovation of the 3PL service provider. Category A5 Service delivery of the 3PL service provider as a category of selection criteria was also rated highly (4.14).

It is plausible to deduce from these results that customer service based on high quality 3PL management abilities is a critical selection criterion. The unidimensional nature of these categories is however an important aspect and one should therefore give attention to the categories of selection criteria which emerge after a factor analysis (discussed in the section on factor analysis and reliability testing). Furthermore, it is useful to identify the most important selection criteria based on individual selection criteria results. The latter aspect is discussed in the next section.

\section{Mean score ranking of the selection criteria}

Of the 44 selection criteria, the top 25 based on the highest mean score values were selected (Table 4). This was done to reflect on the individual selection criteria of greatest importance. These results may assist in the contextualisation of the results reported for categories of selection criteria. The two highest ranked individual selection criteria are Commitment to continuous improvement from the $3 P L(\bar{x}=4.55)$ and Ability of the service provider to provide value-added services $(\bar{x}=4.52)$. The top 10 selection criteria tend to be service and competency based, which support the mean score results per category of selection criteria. It is noteworthy to mention that Cost savings offered by the 3PL service provider was ranked in the 14th place $(\bar{x}=4.12)$. Albeit considered a very important selection criterion, it was not considered the most important criteria item. This finding needs to be contextualised against the view that an important consideration in any logistics system is a trade-off between customer service levels and the costs of those service levels (Pienaar \& Vogt 2016). In the top five are two criteria from the category 3PL resources and technical capability. However, the following three categories are best represented in the top 25: Service delivery of 3PL (5 criteria included), Scope of $3 P L$ services (4 criteria included) and Quality of $3 P L$ service provider (4 criteria included). 
TABLE 4: Third-party logistics selection criteria ranked according to highest mean scores.

\begin{tabular}{|c|c|c|c|c|}
\hline Code & Top 25 selection criteria & Frequency $N$ & Mean & Standard deviation \\
\hline A7.6 & Commitment to continuous improvement from the 3PL service provider & 98 & 4.55 & 0.675 \\
\hline A3.8 & Ability of the 3PL service provider to provide valued added services & 99 & 4.52 & 0.629 \\
\hline A6.9 & Information management and reporting & 99 & 4.49 & 0.629 \\
\hline A1.6 & Demonstration of innovation by the 3PL service provider & 99 & 4.47 & 0.705 \\
\hline A6.8 & Information network security & 99 & 4.38 & 0.634 \\
\hline A2.4 & Sharing of risks between this organisation and the service provider & 98 & 4.38 & 0.780 \\
\hline A3.2 & Ability of the $3 P L$ service provider to provide customised service & 99 & 4.34 & 0.785 \\
\hline A5.1 & Adherence to the contract & 99 & 4.27 & 0.603 \\
\hline A3.3 & Geographical coverage of the 3PL service provider & 99 & 4.21 & 0.594 \\
\hline A5.4 & On-time shipment and deliveries & 99 & 4.18 & 0.787 \\
\hline A1.4 & Accessibility of top management of the 3PL service provider & 99 & 4.17 & 0.686 \\
\hline A5.3 & Accuracy of delivery & 99 & 4.16 & 0.854 \\
\hline A5.5 & Low error rates & 99 & 4.13 & 0.888 \\
\hline A4.2 & Cost savings offered by the 3PL service provider & 97 & 4.12 & 0.462 \\
\hline A6.7 & Information network accessibility & 99 & 4.12 & 0.674 \\
\hline A7.4 & Regulation compliance, e.g. B-BBEE status, risk management (OHS Act) & 99 & 4.12 & 0.812 \\
\hline A4.5 & Low operation costs of the 3PL service provider & 98 & 4.08 & 0.821 \\
\hline A7.1 & Quality of management by the 3PL service provider & 99 & 4.07 & 0.824 \\
\hline A2.5 & Sharing of rewards between this organisation and the 3PL service provider & 98 & 4.05 & 0.778 \\
\hline A4.1 & Favourable price structure of the 3PL service provider & 98 & 4.01 & 0.696 \\
\hline A7.5 & Compliance to environmental requirements by the $3 \mathrm{PL}$ provider & 99 & 3.97 & 0.851 \\
\hline A5.2 & Speed of delivery & 99 & 3.96 & 0.768 \\
\hline A2.3 & Trust between this organisation and the 3PL service provider & 99 & 3.95 & 0.705 \\
\hline A1.3 & Financial stability of the 3PL provider & 99 & 3.93 & 0.689 \\
\hline A3.1 & Range and level of $3 \mathrm{PL}$ service offerings & 98 & 3.93 & 0.911 \\
\hline
\end{tabular}

3PL, third-party logistics providers; B-BBEE, Broad-based Black Economic Empowerment.

The rating of these 25 3PL selection criteria as important in this study aligns with the findings of studies by Menon et al. (1998), Spencer et al. (1994), Moberg and Speh (2004), Qureshi et al. (2007) and Bayazit and Kaprak (2013), which indicated that 'service delivery' and 'quality of management of the 3PL', are the most important selection criteria for users of 3PLs.

\section{Factor analysis and reliability testing}

The 25 selection criteria (items) with the highest mean scores were subjected to an exploratory factor analysis (EFA) to identify interrelationships among variables (Pallant 2007), allowing for the development of a model from a large set of data, and in addition, providing construct validity of the survey (Taherdoost, Sahibuddin \& Jalaliyoon 2014). A factor analysis also assists to remove duplications and redundancy from sets of correlated variables (Garret-Mayer 2006). Although Pallant (2007) recommends a sample size of 300 for factor analysis, Taherdoost et al. (2014:377) cited Hair et al. (1995) indicating that a sample size of 100 or greater is acceptable. Only 25 selection criteria were used for the factor analysis because of the limited number of responses (103). It was not possible to conduct a factor analysis on all 44 selection criteria. For the latter at least 180 responses would have been required. According to the Kaiser-Meyer-Olkin (KMO) value which measures sampling adequacy, a sample size of between 97 and 99 was acceptable, as indicated by the $\mathrm{KMO}$ value of 0.857 . The strength of the relationship between variables was tested using the correlation coefficient. The data were ordered (from highest to lowest) in terms of the mean score values. The reverse scoring was checked using the component matrix, prior to conducting the analysis. From the factor loadings for each of the components two weak items were identified, with measures of sampling adequacies (MSA's) of less than 0.6 - A3.3 the geographical coverage of the $3 P L$ service provider (MSA $=0.464$ ) and A4.2 cost savings offered by the 3PL service provider $(\mathrm{MSA}=0.565)$. These were eliminated. The significance of the Bartlett's test of sphericity proved the factorability of the data with a $p$ value less than 0.05 (Pallant 2007). Factor extraction was done using principal components analysis. With the anti-image correlation results greater than 0.6 , no further items needed to be extracted. The communalities at extraction were between 0.385 and 0.912 , all greater than the required 0.3 . This result confirmed that no further items were to be removed.

With the Kaiser's criterion technique the number of factors for analysis was determined by retaining all factors with Eigen values greater than 1.0. In order to facilitate the interpretation of the results, the factors were rotated. A Varimax orthogonal rotation was used to reduce the number of variables with high loadings on each factor. Five factors with Eigen values greater than 1, accounting for $70.98 \%$ of the variance, were extracted. From the results of the rotated factor matrix all factor loadings of less than 0.25 were excluded (Table 5). The highest loadings on each factor (highlighted in Table 5) were grouped together.

Themes emerged from the items that converged in five factors. The items that had high loads on Factor 1 (8 items) represent Service quality, on Factor 2 (6 items) Information management and compliance and on Factor 3 (6 items) Collaboration (Table 6). Factors 4 and 5 contained fewer than 
TABLE 5: Rotated factor matrix of third-party logistics service provider selection criteria.

\begin{tabular}{lccccc}
\hline Selection criteria & Factor 1 & Factor 2 & Factor 3 & Factor 4 & Factor 5 \\
\hline A5.3 & $\mathbf{0 . 9 1 2}$ & - & - & - & - \\
A5.4 & $\mathbf{0 . 8 9}$ & - & - & - & - \\
A5.2 & $\mathbf{0 . 7 8 5}$ & - & - & - & 0.291 \\
A5.5 & $\mathbf{0 . 7 0 6}$ & 0.286 & - & 0.263 & - \\
A7.1 & $\mathbf{0 . 5 7 9}$ & 0.515 & - & - & 0.275 \\
A3.1 & $\mathbf{0 . 5 2 4}$ & 0.495 & 0.339 & - & - \\
A4.5 & $\mathbf{0 . 5 2 3}$ & 0.438 & 0.291 & - & - \\
A2.3 & 0.523 & - & 0.318 & - & 0.481 \\
A7.4 & - & $\mathbf{0 . 7 8 4}$ & - & - & - \\
A7.5 & 0.441 & $\mathbf{0 . 7 5 3}$ & - & - & - \\
A6.9 & - & $\mathbf{0 . 6 1 1}$ & 0.339 & 0.32 & - \\
A6.7 & 0.291 & $\mathbf{0 . 4 8 6}$ & - & 0.383 & - \\
A6.8 & - & $\mathbf{0 . 4 7 4}$ & 0.437 & - & - \\
A1.4 & 0.313 & $\mathbf{0 . 3 4}$ & - & - & - \\
A2.4 & 0.464 & 0.306 & $\mathbf{0 . 6 9 2}$ & - & - \\
A7.6 & - & 0.511 & $\mathbf{0 . 6 8 1}$ & - & - \\
A1.6 & - & 0.402 & $\mathbf{0 . 6 3 9}$ & - & 0.397 \\
A2.5 & - & - & $\mathbf{0 . 6 1 6}$ & - & - \\
A3.8 & - & - & $\mathbf{0 . 5 4 7}$ & - & - \\
A3.2 & - & - & 0.335 & $\mathbf{0 . 8 2 4}$ & - \\
A4.1 & - & - & - & $\mathbf{0 . 6 1 1}$ & - \\
A1.3 & - & - & - & 0.423 & $\mathbf{0 . 6 0 2}$ \\
A5.1 & 0.375 & - & - & - & $\mathbf{0 . 4 5 4}$ \\
\hline & - & - & &
\end{tabular}

Note: Extraction method: Principal Axis Factoring.

Rotation method: Varimax with Kaiser normalisation.

Rotation converged in eight iterations.

The highest loadings in each factor (bold numbers) were grouped together.

three items and were not retained. From the average mean scores (Table 6), Factor 3 Collaboration had the highest average mean score value of 4.39; followed by Information management and compliance at 4.21 and Service quality at 4.08 . The measure of internal consistency for these three factors exceeded 0.6: Factor $1-0.917$, Factor $2-0.829$ and Factor $3-0.828$

The factor analysis allowed for similar themes to be grouped within the same factor. Based on the criteria in each factor, a name could be given to each factor. Factor 1 was called Service quality, Factor 2 Information management and compliance and Factor 3 Collaboration. In order to rank the factors, the average mean score for each factor was calculated. The factor named Collaboration emerged as most important with the highest average mean score value of 4.39 , followed by Information management and compliance at 4.21 and Service quality at 4.08 .

The results of the factor analysis gives an indication of the importance of the three factors based on unidimensional scales derived from the analysis. More value can be derived from the results of the factor analysis conducted in this study by using it in the further refinement of measurement scales for use in future studies on the topic of 3PL selection criteria.

\section{Ranking of the seven categories of 3PLs selection criteria}

In addition to the ranking of individual selection criteria, respondents were asked to rank the seven categories which contain the 44 3PLs selection criteria, on a seven-point scale $(1=$ most important). From the mean scores of the 98 usable responses (Table 7), the category Cost and pricing structure of
$3 P L$ service provider is ranked as the most important category, with a mean score of 1.99. The category of Service delivery of the 3PL service provider is ranked second with a mean score of 2.18 , followed by the category Potential relationship with the $3 P L$ service provider $(\overline{\mathrm{x}}=2.24)$. To compare the ranking results from the ranking studies conducted by IOMA (2009), Moberg and Speh (2004), and Spencer et al. (1994) with the ranking in this study, is not feasible as the descriptions of the criteria are not exactly the same. Nevertheless, it does seem that service delivery of a 3PL service provider is ranked highly by all these studies.

Based on mean score values only, these results differ from the ranking performed earlier in this study on the selection criteria categories based on mean score values assigned. One potential reason for this lies in the fact that in the last instance, categories of selection criteria were tested using single-item scales. Single-item measures can be used when the construct it measures is unambiguous (Wanous, Reichers \& Hudy 1997). In support of this theory, Loo (2002) warns against the use of single-item scales to measure complex constructs.

Based on the literature study conducted in this study it appears that all the categories of selection criteria can be considered multi-dimensional. Therefore it is suggested that the ranking based on multi-item scales be considered as more reliable.

\section{Need for a 3PL service providers' index in South Africa}

A total of $94 \%$ of the 103 respondents indicated that they were not aware of an existing ranking index in South Africa. An overwhelming majority (90\%) agreed that a ranking index for 3PLs in South Africa would assist their business in selecting 3PLs. From the literature study it appears that the responsibility of selecting 3PLs can be a daunting experience, which could be eased by the utilisation of a 3PLs ranking index. As it does not exist in South Africa, the selection criteria identified by mean scores of the factor analysis can be utilised to develop and test such a 3PLs ranking index.

\section{Limitations and further research}

The strength of the study lies in its inclusion of the Fortune Top 500 Companies in Africa (2013), which are the largest and most notable business enterprises in Africa. Future research could also include the excluded companies in order to generate more inclusive results. This study could be extended to include the small and medium-sized enterprises, given their importance to the economy. Because of the limited number of responses, it was not possible to compare the 3PL requirements of the different industries. With the identified 3PL selection criteria, the study could be extended to obtain sufficient data from the users in different industry sectors for comparative purposes. Furthermore, future research should develop and test the 3PL service provider index. 
TABLE 6: Factors for third-party logistics selection criteria.

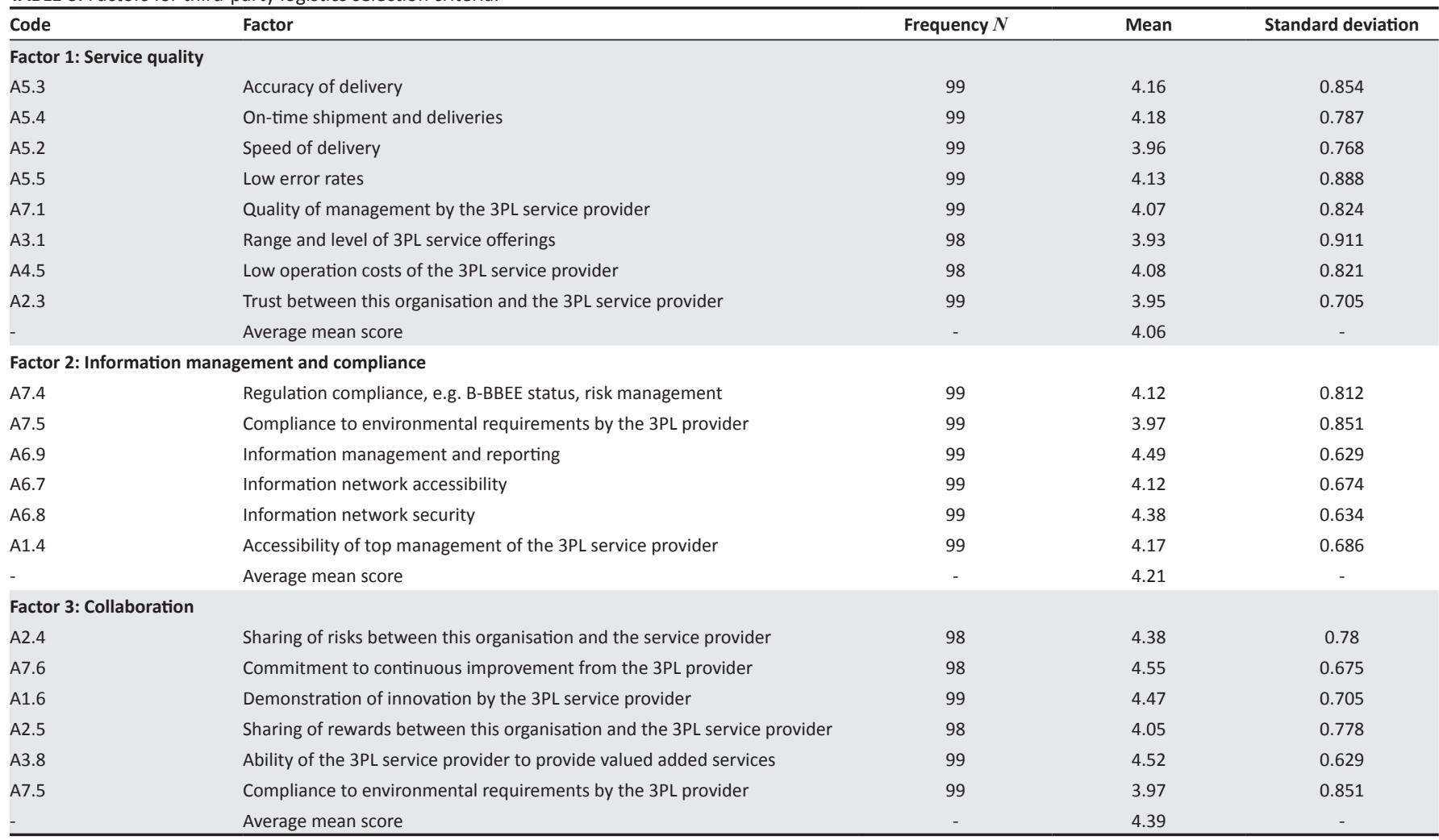

3PL, third-party logistics providers; B-BBEE, Broad-based Black Economic Empowerment.

TABLE 7: Respondents' ranking of the seven categories of third-party logistics selection criteria.

\begin{tabular}{llcc}
\hline Ranking position & Categories of 3PLs selection criteria & Frequency & Mean \\
\hline 1 & Cost and pricing structure of 3PL service provider (A4) & 99 & 1.99 \\
2 & Service delivery of 3PL service provider (A5) & 99 & 2.18 \\
3 & Potential relationship with 3PL service provider (A2) & 99 & 2.24 \\
4 & Credentials of the 3PL service provider (A1) & 99 & 1.562 \\
5 & Scope of services offered by 3PL service provider (A3) & 99 & 2.41 \\
6 & Quality of 3PL service provider (A7) & 98 & 2.67 \\
7 & 3PL resources and technical capability (A6) & 99 & 2.83 \\
\hline
\end{tabular}

3PL, third-party logistics.

\section{Conclusion}

The purpose of this study was to determine the critical selection and ranking criteria for the creation of an index to evaluate 3PLs in South Africa for developing a 3PL benchmarking index. From the literature review 44 3PLs selection criteria were identified for inclusion in the survey to evaluate their relevance and importance to the South African logistics industry. From the 44 criteria for selecting 3PLs, the users rated their importance and it was possible to rank the top 25 by the value of the mean scores. From this list it is possible to compile a 3PL service provider index. However, further refinement of the selection criteria was possible through the factor analysis of the 25 top selection criteria. Three factors comprising 20 items converged. This result would contribute to a further refinement of the index prior to testing.

Customer service and the management quality of 3PLs consistently emerged as very important selection criteria. This finding is consistent with the results of various other international studies conducted on the topic of 3PL selection criteria.

3PLs provide a range of critical services to companies and therefore the decision to select the best service provider becomes strategic, in particular as the relationship with 3PLs tends to be long term. Thus, management could utilise these critical logistics outsourcing selection criteria to evaluate and rank 3PLs prior to contracting. The theoretical implication of this study is that the selection criteria for logistics outsourcing identified and ranked in this article, can form the basis of a ranking index for 3PLs in South Africa which can be tested and further refined.

\section{Acknowledgements}

This article is based on the research conducted for a master's degree study undertaken at the University of Johannesburg entitled 'Selection and Ranking Criteria for a Third-Party Logistics Service Provider's Index in South Africa'. 


\section{Competing interests}

The authors declare that they have no financial or personal relationships that may have inappropriately influenced them in writing this article.

\section{Authors' contributions}

C.K. and M.S. conducted the master's dissertation on which this article is based. E.S. and P.J.K. acted as the supervisors of the said master's dissertation and compiled this article based on it.

\section{References}

Aguezzoul, A., 2014, 'Third party logistics selection problem: A literature review on criteria and methods', Omega 49, 69-78. https://doi.org/10.1016/j.omega. 2014.05.009

Armstrong \& Associates, 2013a, Slow dance 2012-3PL market analysis and 2013 predications, viewed 01 July 2015, from http://www.3plogistics.com/shopsite/ index.html

Armstrong \& Associates, 2013b, Top 25 global freight forwarders, viewed 04 August 2015, from http://www.3plogistics.com/3pl-market-info-resources/3pl-marketinformation/aas-top-25-global-freight-forwarders-list/

Armstrong \& Associates, 2014, Global and regional infrastructure, logistics and third party logistics market trend and analysis, viewed 13 June 2015, from www.3plogistics.com/shopsite/Global_3PL_Market_Analysis_EIS-2014

Armstrong \& Associates, 2015, Online 3PL guide report screen, viewed 13 June 2015 from http://www.3plogistics.com/product/whos-who-in-logistics-online-guide/

Barloworld Logistics, 2014, 2014 Supplychainforesight: The rise and fall of customers and companies, viewed 16 June 2015, from http://www.barloworld-logistics. com/wp-content/uploads/2013/11/supplychainforesight-report-2014.pdf

Barloworld Logistics, 2017, 2016 Supplychainforesight: Navigating smart, viewed 18 January 2017, from http://www.barloworld-logistics.com/supply-chainsolutions/

Bayazit, O. \& Karpak, B., 2013, 'Selection of a third party logistics service provider for an aerospace company: An analytical decision aiding approach', International Journal of Logistics Systems and Management 15(4), 382-404. https://doi. org/10.1504/IJLSM.2013.054898

Braglia, M. \& Petroni, A., 2000, 'A quality assurance-orientated methodology for handling trade-offs in supplier selection', International Journal of Physical Distribution \& Logistics Management 30(2), 96-112. https://doi.org/10.1108/ 09600030010318829

Brewer, B., Wallin, C. \& Ashenbaum, B., 2014, 'Outsourcing the procurement function: Do actions and results align to theory?', Journal of purchasing and Supply Management 20, 186-194. https://doi.org/10.1016/j.pursup.2014.02.004

Chen, H., Tian, Y., Ellinger, A.E. \& Daugherty, P.J., 2010, 'Managing logistics outsourcing relationships: An empirical investigation in China', A Journal of Business Logistics 31(2), 279-299. https://doi.org/10.1002/j.2158-1592.2010.tb00152.x

Coyle, J., Langley R.A., Novack, R.A. \& Gibson, B.J., 2009, Managing supply chains: A logistics approach, 9th Ed, South Western Cengage Learning, Canada.

CSIR, 2014, 10th annual state of logistics survey for South Africa, 2013, viewed 01 August 2015, from http://www.csir.co.za/sol/docs/10th_SoL_Bold_Steps_ Forward_web.pdf

Diabat, A., Khreishah, A., Kannan, G., Panikar, V. \& Gunasekaran, A., 2013 'Benchmarking the interactions among barriers in third party logistics implementation', Benchmarking: An International Journal 20(6), 806-812.

Garret-Mayer, E., 2006, Statistics in psychosocial research. Factor analysis I, The Johns Hopkins University School of Public Health, Baltimore, MD.
Gartner, 2013, The magic quadrant for global third party logistics providers, viewed 16 June 2015, from https://www.gartner.com/doc/2371015/magic-quadrant-globalJune 2015, from https
thirdparty-logistics

Havenga, J.H., Simpson, Z.P., King, D., De Bod, A. \& Braun, M., 2016. Logistics barometer South Africa 2016, Stellenbosch University, Stellenbosch.

Institute of Management and Administration (IOMA), 2009, 'Managing imports and exports', IOMA 9(2), 9-12, viewed 15 March 2015, from http://www.ioma.com/ global

Jacoby, D., 2009, Guide to supply chain management: How getting it right boosts corporate performance, (The Economist Newspaper), Bloomberg, New York.

Jim Wu, Y.C., 2006, 'Assessment of technological innovations in patenting for 3rd party logistics providers', Journal of Enterprise Information Management 19(5), 504-524. https://doi.org/10.1108/17410390610703648

Langley, J. \& Capgemini, 2014, '2014 third party logistics study: The state of logistics outsourcing: Results and findings of the $18^{\text {th }}$ annual study', viewed 15 March outsourcing: Results and findings of the $18^{\text {th }}$ annual study', viewed $15 \mathrm{March}$ 2015, from https://www.capge
study_report_web_version.pdf

Liu, C., Huo, B., Liu, S. \& Zhao, X., 2014, 'Effect of information sharing and process coordination on logistics outsourcing', Industrial Management and Data Systems 115(1), 41-63. https://doi.org/10.1108/IMDS-08-2014-0233

Loo, R., 2002, 'A caveat on using single-item versus multiple-item scales', Journal of Managerial Psychology17 (1),68-75. https://doi.org/10.1108/02683940210415933

Menon, M.K., McGinnia, M.A. \& Ackerman, K.B., 1998, 'Selection criteria for providers of $3^{\text {rd }}$ party logistics services: An exploratory study', Journal of Business Logistic 19(1), 21-37.

Moberg, C.R. \& Speh, T.W., 2004, 'Third party warehousing selection: A comparison of national and regional firms', American Journal of Business 19(2), 71-76. https:// doi.org/10.1108/19355181200400013

Mothilal, S., Gunasekaran, A., Nachiappan, S.P. \& Jayaram, J., 2012, 'Critical success factors of supply chain management: A literature survey and Pareto analysis', A Journal of Business 10(2), 2407-2422.

Pallant, J., 2007, SPSS survival manual: A step-by-step guide to data analysis using SPSS Version 15, 3rd edn., Open University Press, Maidenhead, Berkshire.

Pallant, J. 2013, SPSS survival manual, 5th edn., McGraw-Hill, Berkshire, England

Pienaar, W.J. \& Vogt, J.J., 2016, Business logistics management: A supply chain perspective, 5th edn., Oxford University Press Southern Africa, Cape Town.

Qureshi, N.M., Abdelhadi, A. \& Shakoor, M., 2014, 'Developing new services for 3PL services providers using fuzzy QFD: A LOGINET case study', IUP Journal of Supply Chain Management 11(3), 7-38.

Qureshi, N.M., Kumar, D. \& Kumar, P., 2007, 'An integrated model to identify and classify the key criteria and their role in the assessment of $3 \mathrm{PL}$ service providers', Asia Pacific Journal of Marketing 20(2), 227-249. https://doi.org/10.1108/ 13555850810864579

Saunders, M., Lewis, P. \& Thornhill, A., 2012, Research methods for business students, $6^{\text {th }}$ edn., Pearson, London, UK.

Soinio, J., Tanskanen K. \& Finne, M., 2012, 'How logistics service providers can develop value-added services for SMEs: A dyadic perspective', International Journal of
Logistics Management 23(1), 31-49. https://doi.org/10.1108/09574091211226911

Spencer, M.S., Rogers, D.S. \& Daugherty, P.J., 1994, 'JIT systems and external logistics suppliers', International Journal of Operations and Production Management 14(6), 60-74. https://doi.org/10.1108/01443579410062095

Taherdoost, H., Sahibuddin, S. \& Jalaliyoon, N., 2014, Exploratory factor analysis: Concepts and theory, Advanced Information School (AIS), Malaysia-Japan International Institute of Technology, Malaysia, viewed 05 December 2015 from http://www.wseas.us/e-library/conferences/2014/Gdansk/MATH/MATH-49.pdf

Top 500 Companies in Africa report, 2013, viewed 02 August 2015, from http://www. theafricareport.com/top-500-companies-in-africa-2013.htm

Wanke, P.F., 2012, 'Determinants of scale efficiency in the Brazilian 3PL industry: A 10-year analysis', An International Journal of Production Research 50(9), 2423-2438. https://doi.org/10.1080/00207543.2011.581005

Wanous, J.P., Reichers, A.E., \& Hudy, M.J., 1997, 'Overall job satisfaction: How good are single-item measures?', Journal of Applied Psychology 82, 247-252. https:// doi.org/10.1037/0021-9010.82.2.247 